\title{
Group Work: A Millennial Myth - Improving Group Work in the Basic Course and Beyond
}

\author{
Chris Gurrie
}

\begin{abstract}
Whether in indirect conversations with students or advisees; or directly assigned in one's own class, it seems today's courses involve a lot of group work and subsequently students are involved in several group assignments: group projects, group presentations, group papers. The literature mostly shows that traditional-aged college students work better in groups. Yet, casual conversations with students in the academy often reveal that they dislike group work. Students will cite the difficult communication with group members or imbalanced workloads. Poor experiences in student work groups can ruin the sense of community within the class and even the institution. This purpose of this body of research was to study students and their preferences when involved in groups and answer the question: is the desire to work in groups simply a Millennial myth?
\end{abstract}

Index Terms-Communication, group work, millennials, learning styles.

\section{PROBLEM/BACKGROUND}

No matter the level of the course, often times communication classes require a group project or assignment of some sort. Basic public speaking courses usually have the "group speech" or group presentation. Upper-level communication and public relations courses may require students to present their work or reports in a group presentation. Arguably there may be hundreds of ways to assign and participate in academic group projects. Yet, one thing is less arguable - that some students complain in one way or another about their group assignments. Whether it is casually, formally, through Email, to classmates or directly to an instructor, this researcher has anecdotally seen a fair amount of complaining about group work.

These complaints are not esoteric by any means. Instructors everywhere hear students complain about any and everything - these are not new phenomena. However, the utterings of student displeasure with group work seem to be in direct juxtaposition to what the current literature says of this topic. Scholars of teaching and learning, and those who research the Millennial (traditional-aged college cohort) generation often posit that this cohort prefers to work in groups. Books on Millennials offer accounts of their propensity to date in groups, work in groups, and learn in groups. Yet, this information simply does not mesh with the number of students the researcher has met who complain of the overabundance and sometimes overburden of excessive collegiate group work.

To that end, the research questions for this study were:

Manuscript received June 12, 2014; revised August 22, 2014.

Chris Gurrie is with the University of Tampa, $401 \mathrm{~W}$. Kennedy Blvd, Tampa, FL: 33606 USA (e-mail: cgurrie @ut.edu).
Q1: Is group work with positive outcomes and student preferences simply a Millennial myth?

Secondary to this question, the researcher inquired:

Q2: Do students prefer to work and communicate within groups in college classes?

The purpose of this paper and ultimately this project and its contribution to the body of communication literature is to discuss the future of group work and its impact in collegiate classrooms. It seems that everything today is done in a collaborative format, but is this ultimately a good idea? Do teacher scholars need to reevaluate how they assign and deliver group projects? This paper reviews the literature, explains the study, examines the results, and discusses the implications in order to answer questions and help teacher scholars for the future.

\section{REVIEW OF THE LITERATURE}

Raised points that help add to the validity of this study [1]. Millennials have been hailed as ideal team players and willing to work in groups. This is based on the premise that they are a product of a postsecondary education steeped in group-based work. According to [2], the learning preferences of Millennials are teamwork, technology, structure, entertainment and excitement, and experiential activities.

In their work [3] articulated some of the Millennial learning behaviors: which were responsible and focused on achievement; had a need to stay connected; had zero tolerance for delays; and had strengths in multitasking, goal orientation, and collaboration. [4] found that "Millennial" students: gravitate toward group activity; identify with their parents' values and feel close to their parents; spend more time doing homework and housework and less time watching TV.

One group of researchers studied groups and found Millennials sometimes prefer to work in teams whenever possible, are tolerant toward diversity, and are comfortable working with innovative technology According to that study, most college students have favorable impressions about participating in group work in their courses [5]. Researchers [6] found that students believe they accomplish more by working in groups than by working alone.

Results [from their study] suggest that for the most part group work is experienced in similar among various groups, and working with slackers has a strong influence on attitudes [7]. Other studies about the effect of group work on achievement suggest that group work is a viable alternative to lecture and other instructional methods, yet the research is limited on how students feel about group work [8].

Ref. [5] also found that group projects are becoming a central feature of many college courses. However, one study 
by [9] found that some professors felt their students had a lack of motivation and competence when it came to performing group work.

Perhaps the collaboration of Millennials through technology leads instructors to believe that group work is the way to go in class. Research on the Millennial generation continuously and consistently mentions technology. [10] stated that the Millennial generation is the first to grow up with technology integrated into their lives. According to [11], the accessibility of electronic mail and other portable communication devices has the potential of connecting the student and individual faculty members 24 hours a day, 7 days 11 a week. [12] found that one of the most significant characteristics of the Millennials is their attachment to, understanding of, and comfort with technology.

Ref. [13] also found that educators often feel perplexed and frustrated in their ability to help Millennial students meet their learning needs. Cultivating awareness of one's own generational learning styles, biases, and prejudices can help faculty members address educational challenges.

Ref. [14] stated that the neomillennial learning style is characterized by social constructivist and experiential learning, including fluency in multiple media that utilizes each for the benefits it can offer; learning based on collectivity seeking, sieving, and synthesizing experiences; and active learning based on experience, including frequent opportunities for reflection, expression through nonlinear, mind mapping, and co-design of learning experiences personalized to individual needs and preferences.

\section{Purpose OF ThIS Study}

The literature mostly cites positive affirmation for group work, Millennials, and the college classroom. Some of the later literature suggests that technology links students together and this too may lead to a collaborative work environment. The purpose of this study was to explore the void that Gottschall and Garcia-Bayonas suggest which is that not much is known about student preference for group work; and, as mentioned before to better help teacher scholars help future students. It is important for the reader to understand student preference, and not the study of group work itself.

\section{A. The Current Study}

The researcher designed a questionnaire to collect data from respondents. The instrument was loaded into Surveymonkey and distributed for response. The study took place at a mid-sized comprehensive university in the Southeastern part of the United States. Student respondents were traditional-aged Millennial students and were from basic communication courses at the institution. Aside from age; gender, race, and other distinguishing characteristics were not collected. It was a sample of 60 student respondents.

\section{RESULTS}

Below are selected questions and results for the purpose of this short article:

1) When you are assigned group work which of the following happens more often:
All students received the same final grade: $72.9 \%$.

Students may receive different grades than other group members: $27.1 \%$.

2) Thinking about your most current or recent academic group experience, would you describe it as:

Excellent 8.5\%

$\begin{array}{ll}\text { Good } & 47.5 \% \\ \text { Fair } & 23.7 \% \\ \text { Poor } & 13.6 \% \\ \text { Terrible } & 6.8 \%\end{array}$

3) Do you like group work?

Yes $\quad 42.4 \%$

No $\quad 57.6 \%$

4) Do you prefer to work in groups?

$\begin{array}{ll}\text { Yes } & 17.2 \% \\ \text { No } & 82.8 \%\end{array}$

5) Have you ever formed your own, ungraded study group? Yes $\quad 45.8 \%$

No $\quad 54.2 \%$

6) Have you privately (either through Email or in person) gone to your professor about group problems?

Yes $\quad 45.8 \%$

No $\quad 54.2 \%$

7) Have you ever done what you would consider more than your fair share (been stuck with all of the work) of the work when working in a group?

Yes $\quad 96.6 \%$

No $\quad 3.4 \%$

8) Have you ever contributed less than you should to a group for one reason or another?

Yes $\quad 40.7 \%$

No $\quad 59.3 \%$

9) What would be your ideal number of group projects per semester?

$35.6 \%$

$2-3 \quad 33.9 \%$

4-5 $\quad 5.1 \%$

$5+\quad 1.7 \%$

$23.7 \%$

10) Do your professors explain the purpose or point of working in groups for particular assignments?

Yes always $\quad 5.7 \%$

More often than not $14.3 \%$

Sometimes $\quad 40 \%$

Hardly ever $\quad 37.1 \%$

Never $\quad 2.9 \%$

11) Is the communication in your groups effective?

$\begin{array}{ll}\text { Yes } & 30.2 \% \\ \text { Sometimes } & 45.3 \% \\ \text { No } & 24.5 \%\end{array}$

In the survey instrument there were three open-ended questions for student responses about group work. The questions and selected responses are listed here:

What are three adjectives you can use to describe group work?

- Tedious, fun, compromising

- Miserable, thoughtless, lazy

- Collaborative, interesting, helpful

- Interaction, work, group-thinking

- Time-consuming, tedious, difficult

- Awful, dumb, pointless 
What do you like least about working in groups?

- Some people don't do their work and the hard workers are stuck doing it with a rush

- Some people don't do the work assigned and then they are clueless when it comes to group work

- Same grades

- Getting times where everyone can meet and people who don't do their share.

- Having work divided up unevenly and trying to communicate with larger groups.

What do you like most about working in groups?

- Students get to interact

- There's more than one opinion on what the answer may be so you will have more information than you would by just doing it alone

- $\quad$ Less work sometimes

- $\quad$ Being able to communicate with other people and work as a team

- Working with people I enjoy spending time with

- Dividing up work so the project seems smaller

\section{DISCUSSION AND CONCLUSION}

At first glance the results seem to indicate what is common among most people when it comes to most anything: some people like it [group work] and some people do not. However, when the questions are more carefully analyzed the story is more conflicted. For example, in question 2) roughly half of the respondents found their experiences with group work either excellent or good. In the same question roughly 36 percent found it fair or poor. So it would seem that the experiences were favorable as the literature suggests.

However, questions 3) and 4) offer an interesting conflict. Question 3) asks if students like group work and 42.4 percent answered yes. Yet, in question 4) students were asked do you prefer to work in groups and only 17.2 percent responded yes. This seems contradictory. Perhaps they may "like" it when they do it, but they do not "prefer" to do it overall. Another pair of questions provided interesting data; question 7) asked if students had ever done what they would consider more than their fair share of the work when working in groups. Almost all of the respondents said yes. Yet, when asked if they had contributed less than their fair share of work, only 40.7 percent stated that they had. Finally, as question 11) states, more than half of the respondents stated that the communication within groups was sometimes good or not good at all.

The open-ended questions did not directly answer the current research questions, but they provide human insight into the thoughts of Millennial students on the idea of group work. This qualitative style of data can provide teacher scholars with a pulse of what students think about group work.

Recall, that the purpose of this study was to answer two main questions:

Q1: Is group work with positive outcomes and student preferences simply a Millennial myth?

Secondary to this question was:

Q2: Do students prefer to work and communicate within groups in college classes?

The data seem to suggest and answer of "maybe" for the first question. The respondents did not prefer to work in groups, yet the often liked group work. Perhaps for the future this question needs to be operationalized further. For question 2 ), the answer is no. Students did not prefer to work in groups, and when asked about communication they said it was sometimes effective, but often times not. Therefore, it seems professors will need to vary the teaching styles they use in addition to assigning group work. For the future, teacher scholars need to be aware of the number of group projects they assign and also be cognizant of the number of group projects students may be receiving in other classes. Recall question 9) where $23.3 \%$ of respondents reported zero as their ideal number of group projects per semester.

\section{LIMITATIONS AND THE FUTURE}

There were some limitations to this study. First, the sample size was small. If the study were to be replicated the future researcher should increase the sample size in order to glean a larger theme from the population. There were also a limited number of questions. Future research into this subject could ask about the types of group projects, the weights of the grades assigned in comparison to other class projects, the selection of one's own team members versus being assigned a group, and the idea of gender-whether men or women tend to prefer groups.

\section{CONClusion, COMMUNICATION, AND THE FUTURE}

The research and literature on Millennials and group work suggest that students work well in groups. Yet, the current study found that they do not prefer to work in groups. For teacher scholars the implication is to constantly check how one is delivering his or her class and how much of that class includes group work - and how the communication within the group is facilitated. This evaluation of teaching-learning best practices will help students learn the material the instructor deems important. Additionally, the future seems like it will continue to require students to work in groups. Technology and social networking is helping to facilitate group work even if it is virtually. Communication teacher scholars need to make sure students understand the reason for group work, help students communicate within groups, and understand the students' feelings toward groups. This study asked questions to answer simple research questions, provided a review of the current literature, explained the researcher's design to better understand students working and groups, and offered suggestions for the future - the future of teachers, scholars, and group Millennial communication and work.

\section{REFERENCES}

[1] T. J. Fogarty, "The millennial lie," Issues in Accounting Education, vol. 23, pp. 369-371, 2008.

[2] C. Raines. (2002). Managing millennials: Connecting generations, the sourcebook. Generations at Work. [Online]. Available: http://www.geneartionsatwork.com/ articles/millennials.htm

[3] M. Mc. Mahon and R. Pospisil, "Laptops for a digital lifestyle: Millennial students and wireless mobile technologies," in ASCILITE 2005 Balance, Fidelity, Mobility: Maintaining the Momentum, H. Goss (Ed.), Brisbane, Australia: ASCILITE, pp. 421-431, 2005.

[4] D. Oblinger and J. Oblinger, "Is it age or IT: first steps toward understanding the net generation," Educase, 2005. 
[5] B. Payne and E. M. Turner, "Students' perceptions of group projects: The role of race, age, and slacking," College Student Journal, vol. 40, no. 1, pp. 132-139, 2006

[6] J. K. Winter and J. C. Neal, "Group writing: Student perceptions of the dynamics and efficiency of groups," Business Communication Quarterly, vol. 58, no. 2, pp. 21-24, 1995.

[7] B. Payne and E. M. Turner, "Students' perceptions of group projects: The role of race, age, and slacking," College Student Journal, vol. 40, no. 1 , pp. 132-139, 2006

[8] H. Gottschall and M. G. Bayonas, "Student attitudes towards group workamong undergraduates in business, administration, education an mathematics," Education Research Quarterly, vol. 32, no. 1, pp. 3-28, 2008.

[9] C. Koh, C. K. Wang, O. Tan, W. Liu, and J. Ee, "Bridging the gaps between students' perceptions of group project work and their teachers' expectations," The Journal of Educational Research, vol. 102, no. 5, 2009.

[10] M. Nikirk, "Today's Millennial generation: a look ahead to the future they create," Techniques: Connecting Education and Careers, vol. 84, no. 5, pp. 20-23, May, 2009.

[11] M. B. Leidman and M. J. Piwinsky, The Perpetual Professor in the 21 st Century University, Indiana: Indiana University of Pennsylvania, 2009.

[12] C. Bracy, S. Bevill, and T. D. Roach, "The Millennial generation: Recommendations for overcoming teaching challenges," Educational Leadership, vol. 15, no. 2, pp. 21-24, 2010.

[13] K. T. Pardue and P. Morgan, "Millennials considered: A new generation, new approaches, and implications for nursing education," Nursing Education Perspectives, vol. 29, no. 2, pp. 74-79, 2008.
[14] M. Mc. Mahon and R. Pospisil, "Laptops for a digital lifestyle: Millennial students and wireless mobile technologies," in ASCILITE 2005 Balance, Fidelity, Mobility: Maintaining the Momentum, H. Goss (Ed.), Brisbane, Australia: ASCILITE, pp. 421-431, 2005.

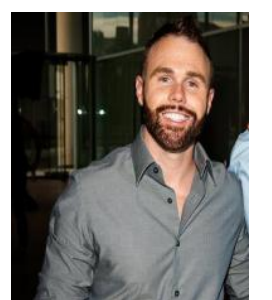

Chris Gurrie resides in Tampa, Florida, USA. He received his bachelor of organizational communication from Purdue University in Indiana, USA; $\mathrm{He}$ received his master of integrated marketing management communication from Florida State University in Florida, USA and his doctor of organizational leadership from Nova Southeastern University in Florida, USA. Gurrie is the director of the speech communication program at The University of Tampa.

He researches communication issues that pertain to immediacy behaviors (non-verbal communication), power point use and misuse, an communication aspects that include millennial students. He applies his research to the fields of social science, communication studies, and the first-year experience. He also participates in invited guest workshops on ways for participants to improve presentation and communication practices.

Dr. Gurrie is a member of the national communication association (US) and is the 2014 chair of the communication and the future division. He chaired the first year committee at The University of Tampa and was named Florida Communication Association's 2011 "Teacher of the Year". 